Article

\title{
Community, Commons, Common Sense
}

\author{
Thijs Lijster \\ Faculty of Arts, University of Groningen, The Netherlands; t.e.lijster@rug.nl
}

Submitted: 25 August 2021 | Accepted: 29 November 2021 | Published: 22 February 2022

\begin{abstract}
As De Angelis, Federici, and others have noted, there are "no commons without community." The concept of community, however (as, among others, Jean-Luc Nancy and Roberto Esposito have shown), has a dark history continuing up until today, when extreme right-wing or even downright fascist appropriations of the concept have understood it as a static and identitarian unity bound to a specific territory or ethnicity. While commons-scholars try to circumvent this legacy by emphasizing the commons as a "praxis" (Dardot and Laval) or "organizational principle" (De Angelis), they thereby tend to neglect the important cultural and symbolic connotations of the concept of community (which, in part, seem to make right-wing movements appealing for certain segments of the population). In my article, I want to raise the following question: Do we need a sense of community for a politics of the commons, and, if so, what concept of community should it be? To answer this question, I will refer back to the use of the concept of "common sense" (sensus communis) in Immanuel Kant's Critique of Judgment. Characteristic of Kant's use of the term is that it does not refer to an actually existing community, but rather to an imaginary community that is anticipated in our (aesthetic) judgment. Common sense, in other words, involves "acting as if" - with the dual dimensions of acting (i.e., the community is based in praxis) and as if (an imagined, anticipated community bordering between the fictional and the real).
\end{abstract}

\section{Keywords}

common sense; commons; community; imagination; Kant; Rancière

\section{Issue}

This article is a part of the issue "The Politics and Aesthetics of the Urban Commons: Navigating the Gaze of the City, the State, the Market" edited by Peer Smets (Vrije Universiteit Amsterdam) and Louis Volont (Massachusetts Institute of Technology).

(C) 2022 by the author(s); licensee Cogitatio (Lisbon, Portugal). This article is licensed under a Creative Commons Attribution 4.0 International License (CC BY).

\section{Introduction}

Despite, or perhaps precisely because of its long and, at times, dark history, the concept of "community" continues to concern us. In Jean-Luc Nancy's words, community "haunts us, as it abandons us or as it embarrasses us" (Nancy, 2003, p. 27). Today, there are at least two reasons to think about the concept. The first is, obviously, the rise of extreme right-wing or downright neofascist movements that mobilize the concept to funnel discontent. These movements understand community as a clearly delineated and identifiable unity bound to a specific territory or ethnicity-a unity that is under constant threat from hostile elements, either from outside or from within. Progressive politics has rightfully criticized this concept, unmasking it as a form of ideology, but thereby it has often tended to neglect its important cultural, symbolic, and emotional connotations (which, in part, seem to make right-wing movements so appealing in the first place, at least for certain segments of the population).

A second reason is the re-emergence of the concept of the "commons" amongst the left-both in activist circles and scholarship-since the beginning of the century, and especially since the economic crisis of 2007. Talking about the commons has allowed us to see how many contemporary social struggles and activist movements are or can be connected. From environmentalism to the "right to the city," and from creative commons and "copyleft" on the internet to land reform and the redistribution of wealth-all of these can be considered as forms of resistance against the enclosure, appropriation, or destruction of the commons and attempt to, in Klein's (2001) words, "reclaim the commons." 
This phrase of "reclaiming," however, immediately raises the question of who should own the commons, or "govern" them (Ostrom, 1990). There are, after all, "no commons without community," as Federici (2019, p. 110) recently wrote. This question becomes all the more pressing considering that the "new enclosures" concern commons, and hence communities, that are less clearly defined and bounded than the ones studied by Ostrom. Who is and who is not part of an urban or online community is not as easily determined as who is part of a Zanjera irrigation community in the Philippines (Ostrom, 1990, pp. 82-88). In this article, I want to address the following question: Do we need the concept of community for a politics of the commons, and, if so, what concept of community should it be? To answer this question, I will first contrast an ontological approach to community to the practical/materialist approach dominant in commons scholarship, arguing that both are ultimately insufficient. Next, I will propose an aesthetic approach based on the Kantian concept of sensus communis and Jacques Rancière's concept of consensus. I will argue that the concept of community that belongs to the politics of the commons is a "dissensual community," revolving around an "acting as if," with the dual emphasis on acting (i.e., a community based on praxis) and as if (an imaginary, anticipated community), that borders between the fictional and the real.

\section{Ontology and Praxis}

In the 1990s, as a response to both the fall of the Berlin Wall and the resurgence of different nationalisms, there was a renewed interest in the concept of community within continental (post-)phenomenological philosophy in the works of, among others, Jean-Luc Nancy and Roberto Esposito (on whom I will primarily draw here). Modern sociology and political thought, from Ferdinand Tönnies to John Rawls, generally made the rather strict distinction between "community" (Gemeinschaft), as the organic unity characteristic of small and historical societies, and "society" (Gesellschaft) as the aggregate of atomistic individuals in modern societies. The Italian philosopher Roberto Esposito, however, argues that the concept of community, from the outset, contains a contradiction within itself. While the community has been traditionally understood in terms of the "proper" - that is, what belongs to me (and to which I belong) in the most intimate sense-he takes a radically different approach: "The common is not characterized by what is proper but by what is improper, or even more drastically, by the other" (Esposito, 2010, p. 7). Going back to the roots of the term communitas, in Greek philosophy and Roman law, he demonstrates that the munus in com-munity refers to an obligation, an official task, or a gift (a gift given but not received). Cum-munus, then, is the sharing of such an obligation, a shared responsibility or indebtedness. Following this, Esposito says that community, therefore, should not be understood in terms of prop- erty: that is, neither as a shared characteristic (such as the color of one's skin) nor as a shared property (as in a territory). Rather, "community" is defined precisely by a lack of something, or a void. With a play on words, he writes that what we have in common is ni-ente, which means "nothing," but also "no-thing." It is, however, precisely this common void that is constitutive of our shared subjectivity, just like the Christian understanding of community consists in the shared loss of Christ, which bestows upon us a shared task and responsibility.

In Esposito's view, modern political thought, since Thomas Hobbes, consists precisely in the denial of this void, or an attempt to fill it, which can only lead to authoritarianism. As is well known, Hobbes' Leviathan starts from the presupposition of the "state of nature," in which sources are scarce and people are more or less equal in physical strength, which means that we are in a permanent "war of all against all." The most basic social relation for Hobbes is thus characterized by competition and fear, and all that we have in common is the capacity to hurt and kill one another. Our only option, and our only rational choice, is hence to collectively submit to some higher authority-the sovereign ruler and state-who consequently acts, in Hobbes' political philosophy, as a replacement for all human relations. As Esposito (2010, p. 27) phrases it:

If the relation between men is in itself destructive, the only route of escape from this unbearable state of affairs is the destruction of the relation itself. If the only community that is humanly verifiable is that of crime, there doesn't remain anything except the crime of the community: the drastic elimination of every kind of social bond.

As a consequence, the social contract is basically a form of immunization, that is the denial or erasure of our shared obligations to one another: Im-munus is then understood, in the legal and political sense, as being exempt from an obligation, office, or task. The original void of the munus is "filled," as it were, by what Esposito calls a "third," that stands above the people: In Hobbes, it is no longer our shared void or weakness, but rather our submission to the Leviathan that binds and connects us, which implies that a horizontal social relation is replaced by a vertical one-of each individual to the state.

In this way, throughout modern political history, there has been a constant tension between the "improper" community, bound by a shared void or lack of something, and the attempts (often by the state) to "immunize" the community against the void of the improper, precisely by defining it on the basis of a shared characteristic (blood) or property (soil). The process of immunization, even if it is meant to protect it, thus always tends to turn against the community itself. And although not all modern political thought has been as explicitly authoritarian as Hobbes', Esposito argues that, therefore, any attempt to define what is common to the 
community-i.e., any attempt to replace the no-thing with some-thing-must lead to totalitarianism: "It's only through the abolition of its nothing that the thing can finally be fulfilled. Yet the realization of the thing, which is necessarily phantasmic, is precisely the objective of totalitarianism" (Esposito, 2010, p. 143).

The strength of such an ontological approach to the concept of community, beyond its philosophical and historical interests, lies in its potential to deconstruct any attempt to define community on the basis of a particular property, that is inherently exclusionary and hence undemocratic. Ontology can thus serve as a basis of a critique of communitarian, nationalistic, and (neo)fascist ideologies. The question is, however, whether it can be made politically productive beyond ideology critique, since, as Dardot and Laval (2019, p. 190) have stated, "the passage from ontology to politics can only ever be a leap of faith." Indeed, following this ontological line, community is "always already" present, as it implies, in Nancy's (2010, p. 148) words, "that the with belongs to the very constitution or disposition or, as you may wish to say, to the being of us." But if being is, in Nancy's Heideggerian phrasing, always "being-incommon" or "being-with," it is still unclear how we could distinguish between forms of political praxis that are more or less "communal," and hence, what precisely the political significance of this ontology of community is. Esposito (2010, p. 140) acknowledges this when he writes that communitas, as he understands it, is ultimately "impolitical":

[It] doesn't keep us warm, and it doesn't protect us; on the contrary, it exposes us to the most extreme of risks: that of losing, along with our individuality, the borders that guarantee its inviolability with respect to the other; of suddenly falling into the nothing of the thing.

I want to contrast this ontological approach to the concept of community with the materialist one that is connected to the aforementioned emergence of commons-scholarship. Elinor Ostrom, in her landmark study Governing the Commons (1990) described and investigated common-pool resources (CPRs) such as meadows, forests, water basins, and fishing ponds that were owned, shared, and governed by a local community. Against the tradition in economic thought that considered commons to be inherently unsustainable (e.g., the infamous "tragedy of the commons" by Garret Hardin), she showed that commons were in fact highly efficient and a viable alternative to private or public (i.e., state-)ownership. While her case studies concern rather traditional and clearly delineated commons, the concept of the commons has also (by Ostrom herself, as well as by others) been applied to cultural, artificial, and digital commons such as knowledges, information, and artistic practices, and also to an urban context. In fact, several authors challenge the idea that commons are a particular "type" of resource with certain "natural" characteristics that make them more likely to be governed as commons (for instance, objects that are non-extractable or boundless, such as air, running water, or beaches). "Against this naturalism," Dardot and Laval write (2019, p. 21), "we must insist that there is no natural standard of unappropriability, and any such norm can only be a legal norm." David Harvey likewise argues that, in the same way that any resource can be appropriated and enclosed by capital, anything can be or become a commons; therefore, it makes more sense to focus on "commoning" as an activity rather than on CPRs as a particular resource (Harvey, 2012, p. 73). Interestingly, he exemplifies the process of commoning by referring to urban movements concerned with the "right to the city" and the different movements of squares, such as Indignados, Occupy, and the Arab Spring uprisings. These movements resignified urban spaces and contested their status as either public or private goods. Through processes like gentrification, regeneration, and Disneyfication, wealth that was created in common by urban dwellers is extracted and turned into private property. This common wealth, however, should not be considered separate from the activity of commoning -it is rather capital that first separates them. As Bollier (2014, p. 15) writes, the concept of commons already involves this activity, as well as the people who are involved in it:

Commons certainly include physical and intangible resources of all sorts, but they are more accurately defined as paradigms that combine a distinct community with a set of social practices, values and norms that are used to manage a resource. Put another way, a commons is a resource + a community + a set of social protocols. The three are an integrated, interdependent whole.

This implies that, in this line of thought, the concept of community is, reversely, necessarily related to practical and productive activity; or, to put it otherwise, the "community" is understood as the plurality of people (or commoners) who do the work of commoning, i.e., the collective sharing, producing, and governing of a particular resource or value.

A clear upshot of this concept, vis-à-vis both the reactionary one and the ontological approach, is precisely its materialist, anti-metaphysical and anti-ideological nature. Although they acknowledge that commons can be-and, indeed, traditionally often have been-xenophobic and patriarchal, Federici and De Angelis argue that this practical, materialist conception makes a community at least potentially more open and inclusive: community is what materially produces and what is in turn produced by the commons, which means that whoever shares in the work of commoning belongs, on that very basis, to the community. For that reason, De Angelis (2014, p. 125) explicitly distinguishes this conception of commons from Benedict Anderson's imagined community: 
Commons thus are not the place for imaginary communities, for those who feel they belong to the same nation, race, or football club without even leaving their private living rooms. Commons are instead made of real communities, in the sense that their practices reproduce not only a network of relations, but also a web of recognizable faces, names and characters and dispositions.

Such a materialist conception, however, comes with its own problems. First of all, it raises the problem of scale. If "community" would indeed be restricted to "recognizable faces," as De Angelis writes, we risk limiting commons to what Srnicek and Williams have provocatively called "folk politics": namely, the romanticization of small-scale localized politics and direct action at the expense of more ambitious, long-term political strategies, the building of sustainable political institutions, and so forth (Srnicek \& Williams, 2015, p. 5). Folk politics would even be contradicting this material, productivist conception itself if we accept Hardt and Negri's argument that the driving force of contemporary capitalist production is "biopolitical labor," i.e., the common production of forms of life (Hardt \& Negri, 2009). After all, such an understanding of capitalism implies an extension of the community even beyond the scope of Marx's proletariat, since biopolitical labor also involves unwaged affective, cognitive, and reproductive labor, and hence, basically involves and binds all of us. For that very reason, Hardt and Negri (2017, p. 99) part ways with those who "insist that the community that shares access and decision-making must be small and limited by clear boundaries to divide those inside from outside" and instead are interested "in more expansive democratic experiences that are open to others."

The question is, though, how and to what extent such an all-encompassing community could actually be recognized as and would consider itself as a community, or, to put it in Hegelese: the extent to which it is not just a community-in-itself but also a community-foritself. While De Angelis (in the quote above) makes a distinction between "imaginary" and "real" communities, I will instead argue that each community must necessarily have an imaginary, fictitious, or, as I will call it, "aesthetic" moment.

\section{Common Sense}

In mentioning the "aesthetic" moment in community, I am not referring to the "aestheticization of politics" that Walter Benjamin associated with fascism. Rather, I am pointing to the fact that the concept of community hangs together with a particular way of sensing the world, and the community itself, or what I will refer to here as "common sense." Common sense has generally been understood in epistemological terms, namely as common knowledge or common opinion, i.e., what everyone thinks is the case and what, therefore, does not need further proof or argumentation. The political relevance of this concept has been pointed out at least since Thomas Payne and later also by Antonio Gramsci, who famously described "hegemony" as the power to define what is common sense (Gramsci, 1971; for a historical overview of the politics of "common sense," see also Rosenfeld, 2011). Here, I want to emphasize a different dimension of common sense-namely, as a shared sense-wherein meaning-making and sensing the world are combined. For that, I will draw on the aesthetic theories of Immanuel Kant and Jacques Rancière.

In the Critique of Judgment (1790), Kant distinguishes aesthetic judgment, or judgment of taste, from other judgments, like logical and moral ones. One of the interesting peculiarities of aesthetic judgment, according to Kant, is that we can offer no proof for them (since they are based on a feeling and hence subjective), and yet we expect that others will agree with us, and may even make claims of universal assent. Taste, as he puts it, is "the ability to judge something that makes our feeling in a given presentation universally communicable without mediation by a concept" (Kant, 1987, p. 162). To explain this peculiarity and justify it, Kant draws on what he calls a sensus communis. He goes on to distinguish his concept from the general use of it as "common human understanding," which he names "vulgar," and "which involves no merit or superiority whatever" (Kant, 1987, p. 160). Instead, he writes:

We must here take sensus communis to mean the idea of a sense shared by all of us, i.e., a power to judge that in reflecting takes account (a priori), in our thought, of everyone else's way of presenting something, in order as it were to compare our own judgment with human reason in general and thus escape the illusion that arises from the ease of mistaking subjective and private conditions for objective ones, an illusion that would have a prejudicial influence on the judgment. (Kant, 1987, p. 160)

For Kant, then, a judgment of taste is "pure" only when we do not consider it ourselves as a purely subjective feeling (which, in the strict sense, it is), but rather as a sensation that we imagine is shared by all. If I am enjoying the sight of a beautiful flower or the sound of a Mozart sonata, I cannot help but expect that others will share my feeling, precisely because there is nothing about me, in particular, that would distinguish my sensation from that of others (or, in Kant's terms, I have no particular interest in the object). Comparing our judgments with those of others, then, does not mean that I adjust my taste to that of the majority (as in the famous phrase that "fifty million Elvis fans can't be wrong"), but rather, reversely, that I presume that my sensation cannot merely be my own, but must be based on some generally shared sense of what is beautiful. Kant even takes this one step further when he states that this means that aesthetic pleasure is derived from the universal communicability of 
our aesthetic judgment, rather than my judgment being based on my subjective pleasure (see Kant, 1987, p. 62).

It is not my intention, here, to elaborate in detail on Kant's aesthetics, which is notoriously complex: As said, I am primarily interested in the concept of sensus communis. Two things make Kant's argument interesting for our present purposes. First, is the already-mentioned emphasis on the aesthetic nature of this common sense (at some point, Kant calls it the sensus communis aestheticus). Common sense is indeed the way we commonly sense the world, a shared sense of our world and of ourselves as community. This is an important addition to the epistemological understanding of the concept and is the way that, for instance, Gramsci used it. Kant's concept of common sense is more fundamental, since it refers not so much to opinions and ideology, but rather to the way in which we experience the world in the first place. Hannah Arendt has pointed out the "hidden" political dimension in this thought. In her Lectures on Kant's Political Philosophy, she states that the third critique is basically about "the insight that men are dependent on their fellow men not only because of their having a body and physical needs but precisely for their mental faculties" (Arendt, 1992, p. 14). What Kant says about aesthetic judgment-namely, that it is based on "universal communicability" and the "public use" of reason-is true for judgments in general, according to Arendt. Taking into account the perspective of others is a fundamental part of what constitutes thought and even what makes us human. It connects the way we experience the world to a community.

The question is, of course, what community we are talking about, which brings me to the second point of interest in Kant's concept of "common sense." As indicated, Kant does not claim that everyone will actually agree with my aesthetic judgment; rather, that the community we appeal to in making aesthetic judgments has the form of the "as if" (als ob). In the passage quoted above, he writes that we "as it were...compare our own judgment with human reason in general" (for an exploration of the "as if" perspective in Kant, see also Früchtl, 2020). He continues:

We compare our judgments not so much with actual as rather with the merely possible judgments of others, and [thus] put ourselves in the position of everyone else, merely by abstracting from the limitations that [may] happen to attach to our own judging. (Kant, 1987, p. 160)

The community to which we relate in our judgments is thus not so much an empirical community, but rather an anticipated community, one that is not (yet) empirically present. That does not mean that this community is entirely fictitious either, but rather that it fundamentally depends (as, again, Arendt already noted) on the power of the imagination: "By the force of imagination it makes the others present and thus moves in a space that is potentially public, open to all sides" (Arendt, 1992, p. 43).

Precisely therein lies the political, if not revolutionary, potential of the Kantian notion of "common sense" and its relation to the concept of community. The community of the commons, I would argue against De Angelis, is in fact an "imagined community," though not only or not so much an imagination of the community as it currently is (as emphasized in the concept of Benedict Anderson) but rather an imagining of what community could be or become. It is to be emphasized that "imagination" here is not an individual matter (like a mental picture in my head), but itself a collective or common feature; it is nourished and shaped by aesthetic experiences, stories, and so on. Furthermore, going beyond Kant, I would underline the practical dimension of this form of imagination: namely, in the attempts to realize and reproduce in reality the common of community. Haiven and Khasnabish have called this "radical imagination": the ability to imagine the world and the community otherwise. They add, however, that the radical imagination "is not just about dreaming of different futures. It's about bringing those possible futures "back" to work on the present, to inspire action and new forms of solidarity today" (Haiven \& Khasnabish, 2014, p. 3).

\section{Consensus/Dissensus}

Whereas Gramsci talked about "common sense" (senso comune) as shared opinions, knowledges, and worldviews, and Kant considered sensus communis as a shared mode of experience, the French philosopher Jacques Rancière attempts to tie these two different meanings together in what he calls "consensus." This term might be somewhat confusing, since we tend to associate it with the outcome of political deliberation-especially considering the centrality of the term in Habermas' writings. From this association, Rancière explicitly distinguishes his use of the term:

Consensus means far more than simply a new way of governing that, in order to avoid conflicts, appeals to expertise, arbitration and the agreement of the respective parts of a population. Instead, consensus is an agreement between sense and sense, in other words between a mode of sensory presentation and a regime of meaning. (Rancière, 2010, pp. 143-144)

Consensus is precisely the point where aesthetics and politics meet, in what Rancière elsewhere calls, respectively, the aesthetics of politics and the politics of aesthetics. Aesthetics and politics, as he understands them, are forms of partage du sensible (distributing of the sensible)-a formulation in which, according to good French tradition, both terms have multiple meanings. "Sensible" has the already-mentioned double meaning of what can be understood and what can be perceived (Rancière, 2004, p. 12, speaks of "self-evident facts of 
sense-perception"), and partage can both mean "to divide" (and thus, to separate) and "to share." What we are able to see, hear, feel, imagine (and so on) together determines our common world: In other words, this sensory space is what we share. Yet, at the same time, it is that which distinguishes and divides us, since not everyone is equally visible, audible, etc. Some groups of people are obviously better represented than others in the media and in parliament, and even in public spaces. In cities, most notably, certain groups can literally disappear from sight. Gentrification, for example, makes people from lower classes invisible in city centers where they can no longer pay the rent, while, for instance, the design of city benches-making it impossible to sleep on themkeeps homeless people out of parks.

This also means that politics entails much more than deliberation over-and development of policies and laws within - state institutions. This, what we usually call politics, is what Rancière calls the "police order," and its function is to sustain and manage a particular distribution of the sensible: that is, a certain division of society into groups, positions, and functions in which each has his or her proper "part" in and of the division. Actual politics, according to Rancière, consists precisely in an interruption of that order by what he calls "the part of those who have no part" (le part des sans part). This means that a group of people who were, up until then, invisible or unheard now make themselves visible (or audible, etc.). Historical examples are, of course, the struggle for universal suffrage by workers and women who had hitherto gone without political representation, or the American civil rights movement. To take a more recent example, one can also think of the Fridays for Future demonstrators, also known as "climate strikers"-mostly underage students who take to the street, precisely because they have no voting rights and are therefore not politically represented. In doing so, they make themselves and future generations-i.e., those for whom the most is at stake in the political struggle over a habitable future planet-visible (see De Cauter, 2021, p. 132). This is the "aesthetics" of politics, namely, that politics is fundamentally about who can make themselves visible and audible in the common domain of experience, and the fact that, as a result of political struggle, the domain is redistributed insofar as those who were invisible become visible. However, Rancière also emphasizes that this redistribution is never finished or settled for once and for all: There will always be a "part that has no part" that might challenge and interrupt the existing order. Consensus should, therefore, not be considered the goal of politics; on the contrary, politics is essentially the creation of "a new form, as it were, of dissensual 'commonsense"' (Rancière, 2010, p. 139).

This form of dissensus is also, in his view, what art and politics have in common: "Art and politics both define a form of dissensus, a dissensual re-configuration of the common experience of the sensible" (Rancière, 2010, p. 140). Although art, and the question of to what extent it should or should not be politically "committed," is not our primary concern here; nevertheless, it is relevant to briefly look at what Rancière writes about the "politics of aesthetics" (for a more elaborate discussion of this question in relation to Rancière's aesthetics see Lijster, 2021). For him, art is always political in a certain sense: namely, to the extent that it always participates in and contributes to a certain distribution of the sensible. Hence, a work of art does not have to convey an explicit political message, or otherwise "activate" the spectator, in order to be political. Rancière is even quite skeptical towards artistic practices that feel the need to bring the "outside world" to the art world, or vice versa (for instance, by organizing political rallies in art institutions, or by putting "ordinary" peoplepreferably from marginalized groups-on the theater stage). Paradoxically, such artistic practices actually confirm the misconception that there is a strict distinction between an artwork over there and a "real world" over there. But, according to Rancière (2010, p. 48):

There is no "real world" that functions as the outside of art. Instead, there is a multiplicity of folds in the sensory fabric of the common, in which outside and inside take on a multiplicity of shifting forms....There is no "real world." Instead, there are definite configurations of what is given as our real, as the object of our perceptions and the field of our interventions.

By this, he does not mean that there are no facts or truth, but rather that those facts and truth, and the extent to which they are visible, are always the outcome of a political struggle and subject to public discussion and investigation (take, for example, again, the climate catastrophe and the extent to which the facts about it have for decades been obscured and made invisible in official policy-making and public debate). Just as art is always already part of the "real" world, this said world "always is a matter of construction, a matter of a 'fiction."' Rancière (2010, p. 149) argues:

Political and artistic fictions introduce dissensus by hollowing out that "real" and multiplying it in a polemical way....The practice of fiction undoes, and then re-articulates, connections between signs and images, images and times, and signs and spaces, framing a given sense of reality, a given "commonsense." It is a practice that invents new trajectories between what can be seen, what can be said and what can be done.

Now connecting Kant to Rancière, I would argue that such political and artistic fictions thereby anticipate a particular type of community, a community characterized by "dissensual commonsense." This is, in other words, a community constituted not by consensus, but rather by dissensus: a dissensual community. While in a consensual community, everyone has and knows their 
"proper" place, a dissensual community is, with reference to Esposito, improper. A well-known historical example of a political action that brings about such a dissensual community is that of Rosa Parks, who refused to give up her seat on the bus to a white passenger in the segregated America of the 1950s. By not sitting in her "proper" place (that is, in a "colored" row on the bus), she created a sense of an improper, dissensual community. Thus, she anticipated what Rancière also calls a "community of equals" - namely, a community that not so much shares a property, but only the demand to be treated equally. Likewise, the Black Lives Matter demonstrations, which spread across the world during the summer of 2020, showed that racism is still ubiquitous and that it is not so much a remnant of the past or a personal flaw or character trait of a few, but a systemic flaw in government institutions like the police, the carceral system, as well as in education, media, etc. As a result of these political actions, and by making visible something that has been invisible, a consensus was broken and things were up for discussion that had, until then, been part of the "common sense."

\section{Dissensual and Liminal Community}

Let us now return to the question that we started off with: What kind of conception of community does the politics of the commons require? To answer this question, we have moved from an ontological approach of community to a practical-material conception, finally arriving at an aesthetic conception. I would argue, however, that these strands are by no means mutually exclusive, but rather cumulative: They reinforce and build upon one another. The ontological take, as I have argued, functions as a deconstruction and critique of existing conservative and reactionary concepts of community based on a common property; the practical-materialist concept emphasizes how community is intimately tied to material struggles over the governing of resources and the means of production and reproduction (i.e., the commons); the aesthetic concept, finally, ties community to communicability and regimes of shared meaning and sense-making.

By bringing these different dimensions into dialogue, my attempt has been to sketch the contours of a concept of community that is "improper" (Esposito), and that consists, to speak with Kant, in an "acting as if," in which both the "acting" (practice) and the "as if" (imagination) are of crucial importance. It is, finally, defined by what Rancière termed a dissensual common sense, wherein common sense refers to how we commonly sense the world, and to the way we conceive of ourselves as community. Thus, this concept takes into account the dual dialectic of a community that is, simultaneously, "always already" and always "to come" - thus, never complete-and of a community that is grounded in material praxis but not restricted by it, being sufficiently open to be imagined otherwise. A community, in other words, that happens and appears through our politics, temporarily emerging through the production of the common. We might also say that community, in this way, is understood as a performance, with the three-fold meaning of it as something actually present on stage ("live"), of a play, and of an accomplishment or achievement.

In their account of the urban protests following the Greek debt crisis, and the mass unemployment and poverty that were the result of it, Angelos Varvarousis and Giorgos Kallis give an example of such a community in an urban context. The protests, they argue, were a result of a process of de-identification, in which people from various backgrounds, and without a clearly and previously shared ideological, ethnic, or cultural identity, joined to form new self-organized communities based on the collective management of and access to shared resources (like food, clothes, shelter, and medicine). Opposed to Ostrom's claim that commons need "clear group boundaries," Varvarousis and Kallis (2017, p. 131) describe these common as "liminal":

In liminal commons, instead, the community of the commoners shines through its absence. Some kind of community of course is temporarily emerging for the production of the common. But this is always precarious and often dissolves. The borders of a liminal community are not only blurred. They actually do not exist as such. Liminal commons, in other words, are not defined by exclusion. Because of this they are more likely to happen in spaces where exclusion is not likely or desirable, such as a public square.

I would argue that such a conception of community is not specific for these urban protests but actually characterizes the urban community per se, even though this non-exclusionary, open, and performative character is constantly contested (by identities that want, in Esposito's terms, to fill the void of the munus). Sociologist Richard Sennett and urban designer Pablo Sendra, in their book Designing Disorder (2020), argue, in line with the above theories, that a city benefits from openness, incompleteness, and liminality, and indeed a certain degree of disorder. Only in this way can urban commons and an urban community thrive, instead of being enclosed for a limited segment of the population or being dispossessed by real estate capital. They write: "When the city operates as an open system...it becomes democratic not in the legal sense, but as a tactile experience" (Sendra \& Sennett, 2020, p. 35). Equality and democracy, in other words, are not just a matter of laws but are sedimented in our shared material environment as well as in our shared urban experience, or common sense.

To give one final example of what this might mean for urban aesthetics (in the narrow sense), I want to refer to the Amsterdam-based art project Welcome Stranger, which, since the 1990s, has curated art exhibitions in urban spaces. In the summer of 2021, Welcome Stranger invited four artists-Esther Tielemans, Lily van 
der Stokker, Radna Rumping, and Kévin Bray-to create works of art in various streets of Amsterdam on or near their own homes. The fact that these works appear outside the conventional spaces of the "official" art institutions (museums, art fairs, galleries) influences both the aesthetic and urban experience at the same time. Still, these are not "public artworks" in the regular sense either, since they are created nearby or sometimes literally on the façade of the artists' homes. This makes them simultaneously more intimate. In some cases, the artworks appear as protrusions of the private space of the artist onto the street; in other cases, the street or public space is reflected or projected onto the house. Sometimes, this reflection takes place literally, as in the green foil of the work Scenery by Esther Tielemans, which sparkles at the passer-by like candy wrappers or the foil of a hazelnut bonbon. The title suggests a green landscape but also the green screen used in films to project imaginary backgrounds. With Roof Terrace With Bubble Bath, Lily van der Stokker, a huge text work attached to the roof of her house, delivers a kind of parody of the garish advertising that often mars the public space in cities and the commercialization of living spaces that is encouraged via Airbnb or similar rental sites.

The works developed within the framework of Welcome Stranger exemplify the redistribution of our shared space and, therewith, a recreation of common sense. They demonstrate how one can bring back openness and playfulness in an urban environment that is threatened by enclosure, and how one can, in Sendra and Sennett's (2020) terms, "design disorder." This is a paradox, of course, for how can one design disorder when "design" inherently implies order? The significance of these urban works, however, is that they tilt our view on the urban space. They create space for the unexpected and the uncommon, and thus offer the possibility to resist the invisible hand of urban planners, real estate entrepreneurs, and city-marketers. The artists turn the unsuspecting passer-by into a participant: Places that you would otherwise probably have passed without thinking, places that at first glance might have seemed uninteresting or where there was nothing to do (which usually means, nothing to consume) now become charged with meaning. This meaning is not (yet) fixed, because it is sufficiently open and undetermined to enter into a dialogue with the experience and interpretation of that passer-by. In short, it becomes an invitation or incentive to rediscover the city, thus reclaiming space for play, for commoning, and for an alternative common sense.

A potential critique of this proposed "aesthetic" approach to the community and the commons might be that it reverts to a form of idealism. Did not Marx, in his famous eleventh thesis on Feuerbach, say that philosophers have merely interpreted the world in various ways, when, according to him, the point was precisely to change it? I hope to have made clear, though, that this objection, at least in the present context, rests on a false dichotomy-for two reasons. First, and very generally speaking, the activity of changing the world (i.e., political action) already implies that you have interpreted (and imagined) the world in a different way, that is, that you see the possibility of it being other than it is at present (Marx understood this all too well, of course, otherwise he would not have spent so much time interpreting capitalism in a different way than Adam Smith or David Ricardo).

Moreover, our "interpretation" of the world does not exist merely in our minds; it is reflected in practices, institutions, laws, policies, the urban landscape, etc. Common sense, as I have understood it here, not only refers to a sense of community, but also to the way a community senses: in other words, to what and how we commonly sense. For instance, it determines the extent to which we perceive the things around us as commodities (hence, as private property) or as commons (and hence, as resources to be governed and reproduced in common). This implies that the very existence of commons is dependent on our ability to sense the commons and to conceive of ourselves as community, that is, on our common sense. Indeed, the question of whether we see (sense) and understand (make sense of) something as either "common" or as "commodity" has drastic consequences for our world, and will make the difference between a politics of extraction, exploitation, and inequality, or one of common abundance, mutual care, and democratic governance. Our "common sense," then, is precisely the mediator between theory and practice, and between interpreting the world differently and changing it.

\section{Acknowledgments}

This research was funded by the Flanders Organization for Scientific Research (FWO), as part of the project Sustainable Creativity in the Post-Fordist City, and the Dutch Organization for Scientific Research (NWO), as part of the project Building the Common City. The author would like to thank the editors, Peer Smets and Louis Volont, the two anonymous reviewers, and proofreader Rosie Taekema for their comments on the manuscript.

\section{Conflict of Interests}

The author declares no conflict of interests.

\section{References}

Arendt, H. (1992). Lectures on Kant's political philosophy. University of Chicago Press.

Bollier, D. (2014). Think like a commoner: A short introduction to the life of the commons. New Society Publishers.

Dardot, P., \& Laval, C. (2019). Common: On revolution in the 21st century. Bloomsbury.

De Angelis, M. (2014). Omnia sunt communia: On the 
commons and the transformation to postcapitalism. Zed Books.

De Cauter, L. (2021). Ending the Anthropocene: Essays on activism in the age of collapse. nai010 publishers.

Esposito, R. (2010). Communitas: The origin and destiny of community. Stanford University Press.

Federici, S. (2019). Re-enchanting the world: Feminism and the politics of the commons. Kairos Books.

Früchtl, J. (2020). Sensus and dissensus communis: The comedy of democracy (following Cavell). Aesthetic Investigations, 4(1), 96-111.

Gramsci, A. (1971). Selections from the prison notebooks. International Publishers.

Haiven, M., \& Khasnabish, A. (2014). The radical imagination. Zed Books.

Hardt, M., \& Negri, A. (2009). Commonwealth. The Belknap Press of Harvard University Press.

Hardt, M., \& Negri, A. (2017). Assembly. Oxford University Press.

Harvey, D. (2012). Rebel cities: From the right to the city to the urban revolution. Verso.

Kant, I. (1987). Critique of judgment. Hackett Publishing Company.

Klein, N. (2001). Reclaiming the commons. New Left Review, 9(2), 81-89.

Lijster, T. (2021). The utopia of the new: Groys, Rancière, and the afterlife of Adorno's aesthetic theory. In S. Gandesha, J. Hartle, \& S. Marino (Eds.), The "aging" of Adorno's aesthetic theory: Fifty years later (pp. 313-339). Mimesis International.

Nancy, J.-L. (2003). The confronted community. Postcolonial Studies: Culture, Politics, Economy, 6(1), 23-36.

Nancy, J.-L. (2010). Communism, the word. In C. Douzinas \& S. Zizek (Eds.), The idea of communism (pp. 145-154). Verso.

Ostrom, E. (1990). Governing the commons: The evolution of institutions for collective action. Cambridge University Press.

Rancière, J. (2004). The politics of aesthetics: The distribution of the sensible. Continuum.

Rancière, J. (2010). Dissensus: On politics and aesthetics. Continuum.

Rosenfeld, S. (2011). Common sense: A political history. Harvard University Press.

Sendra, P., \& Sennett, R. (2020). Designing disorder: Experiments and disruptions in the city. Verso.

Srnicek, N., \& Williams, A. (2015). Inventing the future: Postcapitalism and a world without work. Verso.

Varvarousis, A., \& Kallis, G. (2017). Commoning against the crisis. In M. Castells (Ed.), Another economy is possible: Culture and economy in a time of crisis (pp. 128-159). Polity.

\section{About the Author}

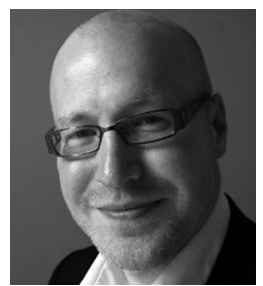

Thijs Lijster is an assistant professor in philosophy of art and culture at the University of Groningen and postdoctoral researcher at the University of Antwerp. His publications include the books Benjamin and Adorno on Art and Art Criticism: Critique of Art (2017) and The Future of the New: Artistic Innovation in Times of Social Acceleration (2018). 